\title{
Osmolyte-induced water deficit stress mitigation during panicle initiation stage in transplanted rice (Oryza sativa L.)
}

\author{
Md. Nurjamal Islam ${ }^{1}$, Abdul Awal Chowdhury Masud ${ }^{1}$, Md. Mahabub Alam ${ }^{1}$, Md. Nurnabi Islam ${ }^{1}$, Mohammed Lutfur \\ Rahman $^{2}$ \& Mirza Hasanuzzaman ${ }^{1^{*}}$
}

${ }^{1}$ Department of Agronomy, Faculty of Agriculture, Sher-e-Bangla Agricultural University, Dhaka-1207, Bangladesh

${ }^{2}$ Farm Management Wing, Sher-e-Bangla Agricultural University, Dhaka-1207, Bangladesh

^Email: mhzsauag@yahoo.com

\section{OPEN ACCESS}

\section{ARTICLE HISTORY}

Received: 02 June 2021

Accepted: 27 July 2021

Available online

Version 1.0: 01 January 2022

\section{Check for updates}

\section{Additional information}

Peer review: Publisher thanks Sectional Editor and the other anonymous reviewers for their contribution to the peer review of this work.

Reprints \& permissions information is available at https://horizonepublishing.com/ journals/index.php/PST/open_access_policy

Publisher's Note: Horizon e-Publishing Group remains neutral with regard to jurisdictional claims in published maps and institutional affiliations.

Indexing: Plant Science Today, published by Horizon e-Publishing Group, is covered by Scopus, Web of Science, BIOSIS Previews, Clarivate Analytics, etc. See https://

horizonepublishing.com/journals/index.php/ PST/indexing_abstracting

Copyright: () The Author(s). This is an openaccess article distributed under the terms of the Creative Commons Attribution License, which permits unrestricted use, distribution and reproduction in any medium, provided the original author and source are credited (https://creativecommons.org/licenses/ by/4.0/)

\section{CITE THIS ARTICLE}

Islam M N, Masud A A C, Alam M M, Islam M N Rahman M L, Hasanuzzaman M. Osmolyteinduced water deficit stress mitigation during panicle initiation stage in transplanted rice (Oryza sativa L.). Plant Science Today. 2022;9 (1):9-20. https://doi.org/10.14719/pst.1256

\begin{abstract}
A field experiment was conducted to observe the osmolyte-induced water deficit stress mitigation during the panicle initiation stage in transplanted rice (Oryza sativa L. cv. BRRI dhan72). At the panicle initiation stage, plants were simulated with four levels of water regimes viz., well-irrigated $\left(D_{0}\right)$, water deficit for $5 \mathrm{~d}\left(D_{1}\right), 10 \mathrm{~d}\left(\mathrm{D}_{2}\right)$ and $15 \mathrm{~d}\left(\mathrm{D}_{3}\right)$. Plants were treated with or without $10 \mathrm{mM}$ of proline (Pro) and trehalose (Tre) as foliar spray started at mid-vegetative stage and continued till the end of stress period. Results revealed that water deficit stress drastically reduced most of the plant morpho-physiological attributes while other yield contributing characters were also affected due to prolonged water deficit stress. However, exogenous application of osmolytes like Pro and Tre significantly increased all those morphological, physiological and yield contributing parameters. Foliar addition of osmolytes concomitantly decreased the number of non-effective tillers hill ${ }^{-1}$ and the number of unfilled grain panicle ${ }^{-1}$ under water stress condition. Although both the osmolytes performed well under multiple duration of drought stress, the application of $10 \mathrm{mM}$ Pro markedly improved all growth and yield contributing parameters under $\mathrm{D}_{1}$ water deficit stress compared to other stress durations. Hence, it may be concluded that the use of osmolytes would be a prospective remedy against moderate water deficit stress in transplanted rice production.
\end{abstract}

\section{Keywords \\ osmolyte, drought, proline, trehalose, relative water content, harvest index}

\section{Introduction}

Adverse environmental conditions like drought, salinity, waterlogging, heavy metals toxicity, nutrient toxicity etc. are the major causes for diminished agricultural productivity worldwide (1). Water deficit stress is a meteorological term, which commonly happens while plant experiences scarcity of water in the root zone due to insufficient rainfall. Worldwide, rice production is reducing due to abiotic stresses where $\mathbf{4 0}$ million hectares of arable rice land in Asia are already affected by drought stress (2). However, drought aggression is increasing in recent years, which would result in reduced global rice production up to $30 \%$ by 2025 (3). Different morpho-physiological alterations in plant such as leaf rolling, reduced number of leaves, small leaf size and stunted growth are common consequences that plants have to face under water deficit condition (4). Drought reduced plant growth, which is mostly dependent on cell elongation, cell division and differentiation and complex interaction including morphological, physiological and biochemi- 
cal events in every growth and developmental stages of plant (5). Furthermore, stomatal conductance, leaf respiration, water use efficiency (WUE), carboxylation, photosynthetic activity, transpiration and enzymatic activities are reduced under prolonged drought condition $(6,7)$. Water deficit stress-induced breakdown of membrane structure causes the disorganization of cellular components, thus the cationic and anion imbalance are accelerated, therefore reduced plant physiological and biochemical activities are observed (8). It was showed that in rapeseed seedlings under prolonged drought condition, membrane lipids peroxidation, hydrogen peroxide $\left(\mathrm{H}_{2} \mathrm{O}_{2}\right)$ production and electrolyte leakage (EL \%) significantly increased and thus hampered the production of chlorophyll (chl) in seedlings (9).

Different strategies are applied to reduce the drought severity by developing tolerance capacity of the crop through exogenous application of plant growth regulators, inorganic and organic nutrients and osmoprotectants that are effective and environmentally safe $(10,11)$. Among these, osmoprotectants maintain water content under drought condition by accumulating various solutes, that are non-harmful to the plant cell and can assist in stabilizing the proteins and cell membranes against stressinduced lethal effects (12). Accumulation and synthesis of osmoprotectants or compatible solutes such as proline (Pro), glycinebetaine (GB), choline, trehalose (Tre), sugars and polyols are vital sources that impart plant tolerance against water deficit stress (3). Water deficit stress has been lessened evidently by the exogenous application of Pro, GB and Tre (13-15). Besides this, osmoprotectants pose defensive role by scavenging reactive oxygen species (ROS). It can scavenge ROS especially the hydroxyl radicle $(\bullet \mathrm{OH})$ from stressed plant cell (16). Osmolyte, like Pro and Tre play significant roles under various abiotic stresses in different crop species $(17,18)$. Proline performs a various role in plant system such as osmotic adjustment, ROS scavenging, maintain cell redox condition, stabilize the subcellular composition and membranes stability that associates with photosystem II and also as a signaling molecules in the plant $(19,20)$. It was observed that, when Pro was used as pre-sowing seed treatment under water deficit stress, seedlings resulted in enhanced root biomass including shoot dry weight (DW), fresh weight (FW), shoot elongation, total grain production in rice (21). In addition, Tre reduced both cell membrane stability and EL along with increased phenolic content, components of carbohydrate content (glucose, sucrose, starch), activities of some antioxidant enzymes, seed yield and yield components in control and drought-stressed cowpea plants (11). It was evident that, water scarcity significantly decreased the growth of plants whereas the spraying of Tre notably increased the plant growth under the same condition (22). Although osmolytes are biosynthesized and accumulated in plant cells naturally under stressful condition, the amount of intrinsic accumulation is trifling compared to the stress severity. Therefore, the exogenous application of Pro and Tre could be a better option to enhance the plant tolerance against drought stress by increasing inter- nal osmolyte content. However, although there are many reports focusing drought adversity on rice plant, there is hardly any study conducted on rice that investigated the role of Pro and Tre on panicle initiation stage. Considering the above circumstances, the present study was undertaken to explore the effects of different duration of water deficit stress at panicle stage and the possible remediation by foliar application of Pro and Tre in transplanted rice.

\section{Materials and Methods}

\section{Plant material and experimental setup}

BRRI dhan72 is a zinc ( $\mathrm{Zn}$ )-fortified modern rice variety popularly cultivated in Bangladesh. It is rich in $8.9 \%$ protein and contain $22.8 \mathrm{mg} \mathrm{kg}^{-1} \mathrm{Zn}$ which is 4 times higher than other popular varieties. Seeds have been collected from Bangladesh Rice Research Institute (BRRI), Gazipur. Seedlings of BRRI dhan72 was previously raised in a wet bed for 25 days. By this time, the main plot was prepared by proper tillage operation followed by puddling for smooth transplanting of seedlings. Recommended doses of fertilizers were applied for proper plant nourishment (23). The whole amount of triple super phosphate (TSP), gypsum, half amount of muriate of potash (MoP) and cowdung were incorporated with soil during final land preparation. Urea was split into two equal volumes and applied at 10 and 20-25 days after transplanting (DAT). Seedlings were transplanted into a prepared land and maintained $(20 \times 15) \mathrm{cm}$ distance. Crop field was kept weed-free throughout the vegetative period after transplanting (30-40 days). Other intercultural operations (gap filling, irrigation, fertilization and pest control) were performed as per requirements. Panicle initiation started at 40 DAT. Water deficit stress was imposed during the panicle initiation stage by withholding water for $5\left(D_{1}\right), 10\left(D_{2}\right)$ and $15\left(D_{3}\right)$ days. Drought was maintained in each plot by raising the boundaries of the plot by clay soil. After designated period of drought stress, plots were re-watered as control was treated. However, controls were remaining irrigated as per water needed from the beginning. Foliar application of Pro and Tre (10 $\mathrm{mM}$ each) was sprayed 4 times at 7 days intervals, starting at the vegetative stage (30 DAT) and continued throughout the full drought period. Around $250 \mathrm{ml}$ of osmolyte solution was sprayed usually at afternoon in each treatment. The experiment was plotted in a randomized completely block design (RCBD). Crop harvesting was executed while 80 to $90 \%$ of the grains become golden yellow. Grains were harvested, threshed and cleaned thoroughly. Different yield parameters were taken after harvesting. Several other morphophysiological data were recorded during the vegetative growth stage from five sampled plants in each treatment.

\section{Measurement of plant height}

Five plants from each plot were randomly selected to measure the plant height at 45 DAT. The length from soil levels to the tip of the leaf was considered as plant height.

\section{Measurement of leaf relative water content}

Relative water content (RWC) was estimated by following 
the Barrs and Weatherley (24) method. From each plot a five leaves samples were collected and weighed as FW and followed by immersing in distilled water for $12 \mathrm{hr}$. Later on, leaves were soaked by paper towel and turgid weight (TW) were weighed. After complete drying of leaves at $80{ }^{\circ} \mathrm{C}$ for $48 \mathrm{hr}$, DW was measured using a balance. The following formula was used to calculate the RWC:

$$
\text { RWC }(\%)=\frac{F W-D W}{T W-D W} \times 100
$$

\section{Measurement of SPAD values}

To measure SPAD value, a chl meter (SPAD, Minolta Camera Co., Osaka, Japan) was used. From three portions of a leaf lamina (top, middle and base) data were taken to measure the chl content under enough sunshine. Five leaf lamina were selected for each treatment and the value of all three portions were averaged (25).

\section{Measurement of yield contributing characters}

Yield contributing characters were observed from 5 randomly selected hills in each treatment. Effective and noneffective tillers were grouped based on the presence of panicle in the tiller. Panicle length was measured from the basal nodes of the rachis to the apex of each panicle. To observe the number of panicle hill-1, a total number of panicles from five selected hills were recorded and averaged. Filled and unfilled grains from five selected panicles of each treatment were separated, counted and averaged. After harvesting, clean and sun-dried 1000 grains were counted from the seed stock and weighed to record 1000-grain weight.

\section{Measurement of yield and harvest index}

Harvesting operation was conducted on $80 \%$ maturity of panicle in each plot. Proper harvesting procedures viz. threshing, cleaning, winnowing and drying were performed systematically. Grain and straw yields were measured from a $1 \mathrm{~m}^{2}$ area. Harvest index $(\mathrm{HI})$ was calculated by the following formula.

\section{Statistical analysis}

For statistical analysis, three replications of field data were tabulated and analysis of variance was done by computer package program CoStat v.6.400 (26). The differences Harvest index $(\mathrm{HI})=\frac{\text { Grain yield }}{\text { Biological yield }} \times 100 \ldots$

among the treatments mean were attuned by least significance difference (LSD) test at 5\% probability (Table 1, 2).

\section{Results}

\section{Plant height}

Plant height was remarkably reduced at different water deficit stress conditions (Fig. 1). However, the application of exogenous protectants significantly recovered plant from stress condition. Water deficit stress reduced plant height at duration-dependent manner where a total of 7,13 and $22 \%$ plant height were reduced due to 5, 10 and 15 days prolong water deficit stress, respectively compared to well-

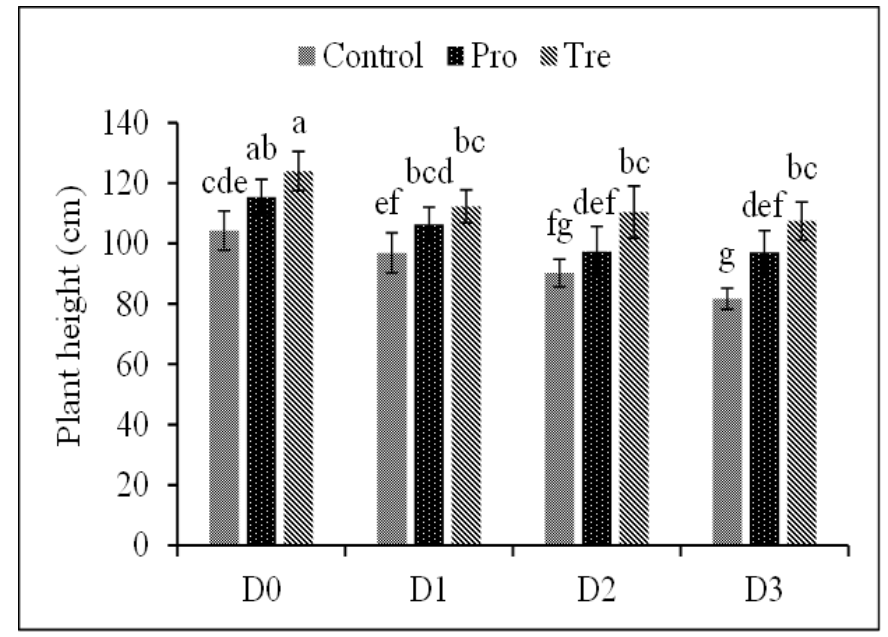

Fig. 1. Effect of different water deficit stress levels and foliar application of Pro and Tre on plant height of rice. Here, $D_{0}, D_{1}, D_{2}$ and $D_{3}$ denotes water deficit at panicle stage for $0,5,10$ and 15 days, respectively. Pro $=10 \mathrm{mM}$ proline, Tre $=10 \mathrm{mM}$ trehalose. Mean $( \pm \mathrm{SD}$ ) was calculated from three replicates for each treatment. Values with different letters are significantly different at $P$ $\leq 0.05$ applying Fisher's LSD test.

irrigated condition. On the contrary, plant height was enhanced while foliar Pro and Tre were applied. The highest plant height was observed in control condition while 15, 19 and 25\% increase were recorded due to application of Tre at $D_{1}, D_{2}$ and $D_{3}$ stressed condition, respectively.

\section{Leaf relative water content}

Relative water content in both main and flag leaf were reduced drastically under drought condition contrast to control. Application of Tre and Pro notably increased the leaf RWC in both main and flag leaf (Fig. 2A, 2B). At $D_{3}$ stress condition, the highest reduction of RWC was observed by 22 and $31 \%$ in the main leaf and flag leaf, respectively. Foliar application of Pro increased 5, 12 and 7\% RWC in main leaf compared to their respective control at $D_{1}, D_{2}$ and $D_{3}$, respectively. However, in main leaf, the highest (19\%) increase of RWC was occurred due to Tre treatment under $\mathrm{D}_{3}$ water deficit stressed condition. In flag leaf, highest (32\%) RWC was observed in well-irrigated condition with Tre application. Ameliorative role of Tre and Pro was also observed under the different duration of water deficit condition. A total of 9, 19 and $21 \%$ enhanced flag leaf RWC was resulted compared to their respective controls due to the application of $10 \mathrm{mM}$ foliar Tre at control at $D_{1}, D_{2}$ and $D_{3}$ stress condition, respectively.

Table 1. Mean squares from analysis of variance (two-ways) of data for growth and yield attributes of rice (Oryza sativa L.) subjected to foliar-applied Pro and Tre under water deficit stress conditions

\begin{tabular}{|c|c|c|c|c|c|c|c|c|c|}
\hline Treatments & df & Plant height & $\begin{array}{l}\text { RWC (\%) } \\
\text { Main leaf }\end{array}$ & $\begin{array}{l}\text { RWC (\%) } \\
\text { Flag leaf }\end{array}$ & $\begin{array}{c}\text { SPAD main } \\
\text { leaf }\end{array}$ & SPAD flag leaf & Effective tillers & $\begin{array}{l}\text { Non-effective } \\
\text { tillers }\end{array}$ & $\begin{array}{l}\text { Panicle } \\
\text { length }\end{array}$ \\
\hline Drought (D) & 3 & $621.63^{\star}$ & $365.75^{\star}$ & $647.25^{\star}$ & $264.82^{\star}$ & $286.88^{\star}$ & $27.33^{\star}$ & $1.55^{\star}$ & $81.86^{\star}$ \\
\hline Osmolyte (0) & 2 & $1234.43^{\star}$ & $228.63^{\star}$ & $291.69^{\star}$ & $104.17^{\star \star}$ & $91.348^{\star \star}$ & $6.56^{\star \star}$ & $0.31^{\star}$ & $53.35^{\star}$ \\
\hline$D \times O$ & 6 & $20.28 \mathrm{~ns}^{\prime \prime}$ & 30.42 ns & $77.97 \mathrm{~ns}$ & $12.66 \mathrm{~ns}$ & $19.94 \mathrm{~ns}$ & $1.90^{\star}$ & $0.03 \mathrm{~ns}$ & $2.86 \mathrm{~ns}$ \\
\hline Error & 22 & 29.77 & 12.91 & 37.93 & 13.91 & 12.25 & 0.55 & 0.02 & 2.86 \\
\hline
\end{tabular}

*,${ }^{\star \star}$ Significant at 0.05 and 0.01 , respectively; ns = non-significant 
Table 2. Mean squares from analysis of variance (two-ways) of data for yield attributes of rice (Oryza sativa L.) subjected to foliar-applied Pro and Tre under water deficit stress conditions

\begin{tabular}{|c|c|c|c|c|c|c|c|c|}
\hline Treatments & df & Panicle no. & Filled grain & Unfilled grain & Grain yield & Straw yield & Harvest index (HI) & $\begin{array}{c}\text { 1000-grain } \\
\text { weight }\end{array}$ \\
\hline Drought (D) & 3 & $22.14^{\star}$ & $4871.88^{\star}$ & $181.14^{\star}$ & $3.29^{\star}$ & $2.62^{\star}$ & $189.83^{\star}$ & $72.83^{\star}$ \\
\hline Osmolyte (O) & 2 & $8.74^{\star \star}$ & $647.34^{\star \star}$ & $158.42^{\star}$ & $0.64^{\star \star}$ & $0.98^{\star \star}$ & $44.36^{\star}$ & $12.07^{\star}$ \\
\hline$D \times O$ & 6 & $0.36 \mathrm{~ns}$ & $166.68 \mathrm{~ns}$ & $13.39^{\star}$ & $0.07 \mathrm{~ns}$ & $0.16 \mathrm{~ns}$ & 8.20 ns & $2.55 \mathrm{~ns}$ \\
\hline
\end{tabular}

*, ${ }^{\star \star}$ Significant at 0.05 and 0.01 , respectively; ns = non-significant

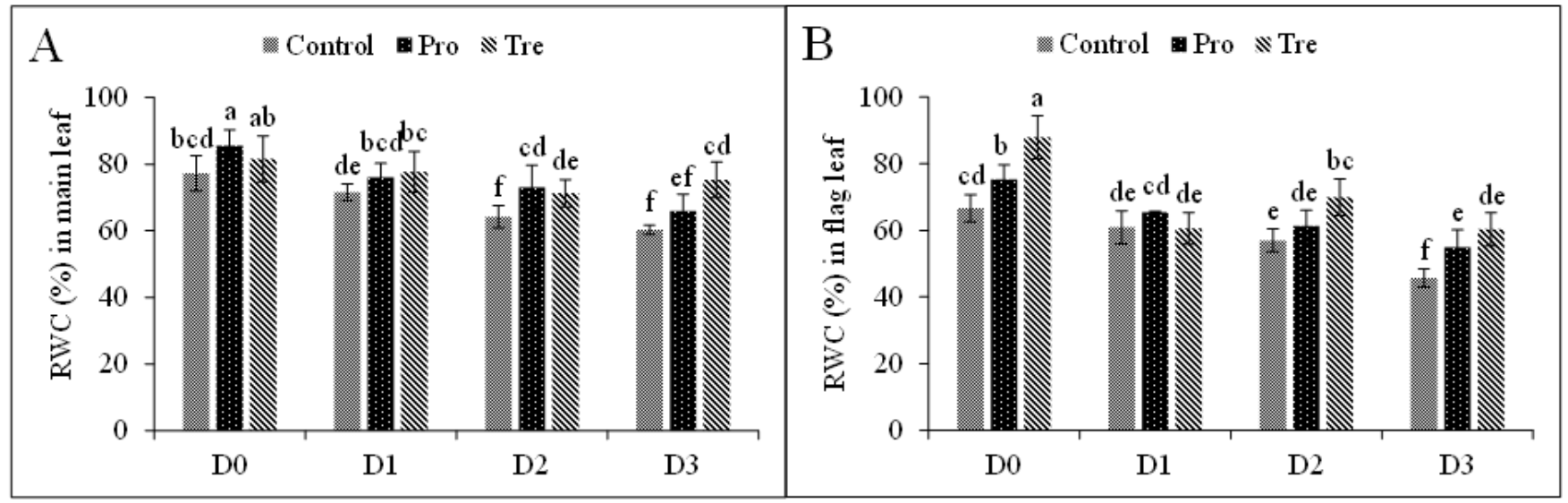

Fig. 2. Effect of different water deficit stress levels and foliar application of Pro and Tre on RWC in main leaf (A) and flag leaf (B) of rice. Here, $D_{0}$, $D_{1}$, $D_{2}$ and $D_{3}$ denotes water deficit at panicle stage for $0,5,10$ and 15 days, respectively. Pro $=10 \mathrm{mM}$ proline, Tre $=10 \mathrm{mM}$ trehalose. Mean $( \pm$ SD) was calculated from three replicates for each treatment. Values with different letters are significantly different at $P \leq 0.05$ applying Fisher's LSD test.

\section{SPAD value}

Upon exposer to water deficit stress at different duration, leaf SPAD value of rice was reduced significantly. Water deficit at $D_{3}$ condition resulted in the highest reduction of SPAD value (29 and $34 \%$ ) in main leaf and flag leaf, accordingly (Fig. 3A, 3B). On the contrary, the application of Pro and Tre greatly increased the SPAD value under water deficit stress condition. Compared to the respective controls, application of Pro increased the SPAD value in main leaf by 11,14 and $14 \%$ under $D_{1}, D_{2}$ and $D_{3}$ stressed condition, respectively. In flag leaf, the highest (19\%) SPAD value was observed due to application of $10 \mathrm{mM}$ Tre under $D_{3}$ stress condition.

\section{Number of tillers}

Prolonged drought stress greatly influenced the rice tillers hill $^{-1}$. Both effective and non-effective tillers were influenced considering the duration of drought period. The highest (36\%) reduction of effective tillers was documented at $D_{3}$ water deficit stress condition during panicle initiation stage. On the other hand, the highest number of noneffective tillers $(87 \%)$ was observed at same water deficit condition (Fig. 4B). Foliar application of Tre greatly improved number of effective tillers hill $^{-1}$ by reducing noneffective tillers in all stress durations except $D_{1}$. The highest number of effective tillers (9\%) was observed at control condition with Tre spray while at $D_{2}$ stress condition, the highest number of effective tillers (17\%) was also recorded with Tre application. Furthermore, both Pro and Tre reduced the number of non-effective tillers hill ${ }^{-1}$ by 25,23 , $23 \%$ and $15,37,26 \%$ under $D_{1}, D_{2}, D_{3}$ water deficit stress

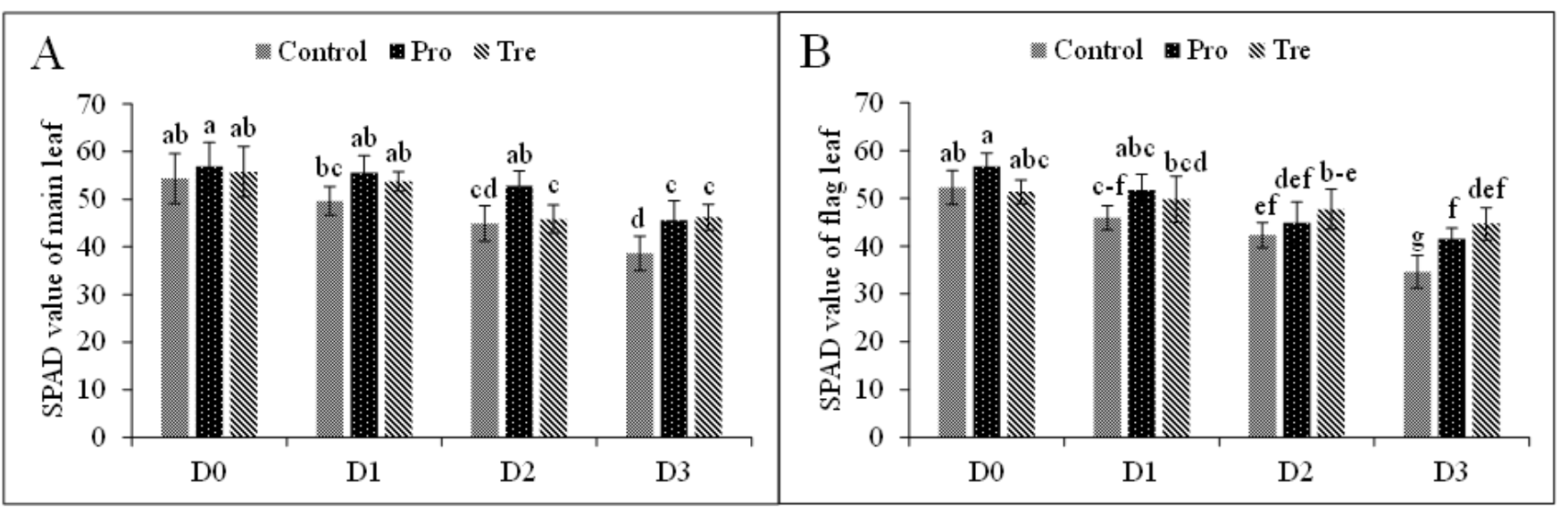

Fig. 3. Effect of different water deficit stress levels and foliar application of Pro and Tre on SPAD value in main leaf (A) and flag leaf (B) of rice. Here, $D_{0}$, $D_{1}$, $D_{2}$ and $D_{3}$ denotes water deficit at panicle stage for $0,5,10$ and 15 days, respectively. Pro $=10 \mathrm{mM}$ proline, Tre $=10 \mathrm{mM}$ trehalose. Mean $( \pm$ SD) was calculated from three replicates for each treatment. Values with different letters are significantly different at $P \leq 0.05$ applying Fisher's LSD test 


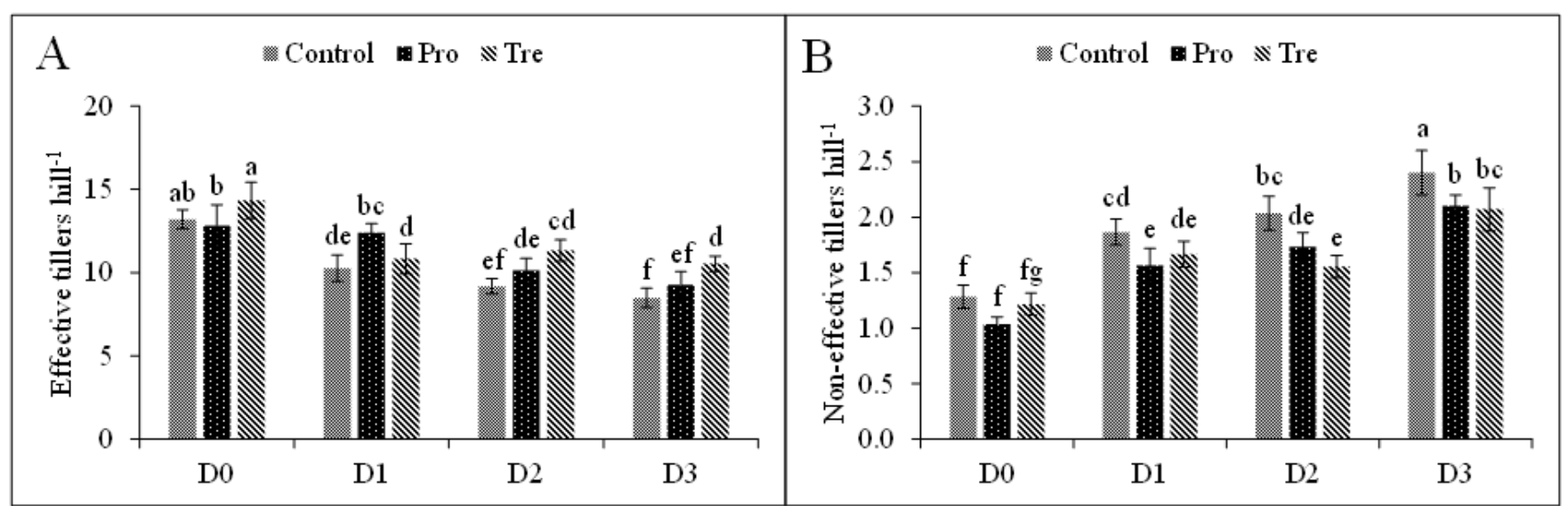

Fig. 4. Effect of different water deficit stress levels and foliar application of Pro and Tre on number of effective tillers hill-1 (A) and non-effective tillers hill-1 (B). Here, $D_{0}, D_{1}, D_{2}$ and $D_{3}$ denotes water deficit at panicle stage for $0,5,10$ and 15 days, respectively. Pro $=10 \mathrm{mM}$ proline, Tre $=10 \mathrm{mM}$ trehalose. Mean $( \pm S D)$ was calculated from three replicates for each treatment. Values with different letters are significantly different at $P \leq 0.05$ applying Fisher's LSD test.

condition, respectively.

\section{Panicle length}

Panicle length was sharply reduced due to water deficit stress. The highest reduction of panicle length (27\%) was recorded under $D_{3}$ stress condition followed by 26 and $14 \%$ in $D_{2}$ and $D_{1}$, respectively (Fig. 5A). Application of Pro and Tre notably increased the panicle length whereas the highest panicle length $(11 \%)$ was observed in $10 \mathrm{mM}$ Pro application. Under water deficit stress condition at $D_{1}, D_{2}$ and $D_{3}$, Pro increased panicle length by 15,16 and $13 \%$, respectively. On the contrary, Tre increased panicle length by 12,23 and $9 \%$ under $D_{1}, D_{2}$ and $D_{3}$ water deficit condition, respectively.

\section{Number of panicles hill- ${ }^{1}$}

Panicle number was also decreased under water deficit stress by 16,23 and $26 \%$ at 5, 10 and 15 days of water deficit stress, respectively, compared to control. (Fig. 5B). Alt-
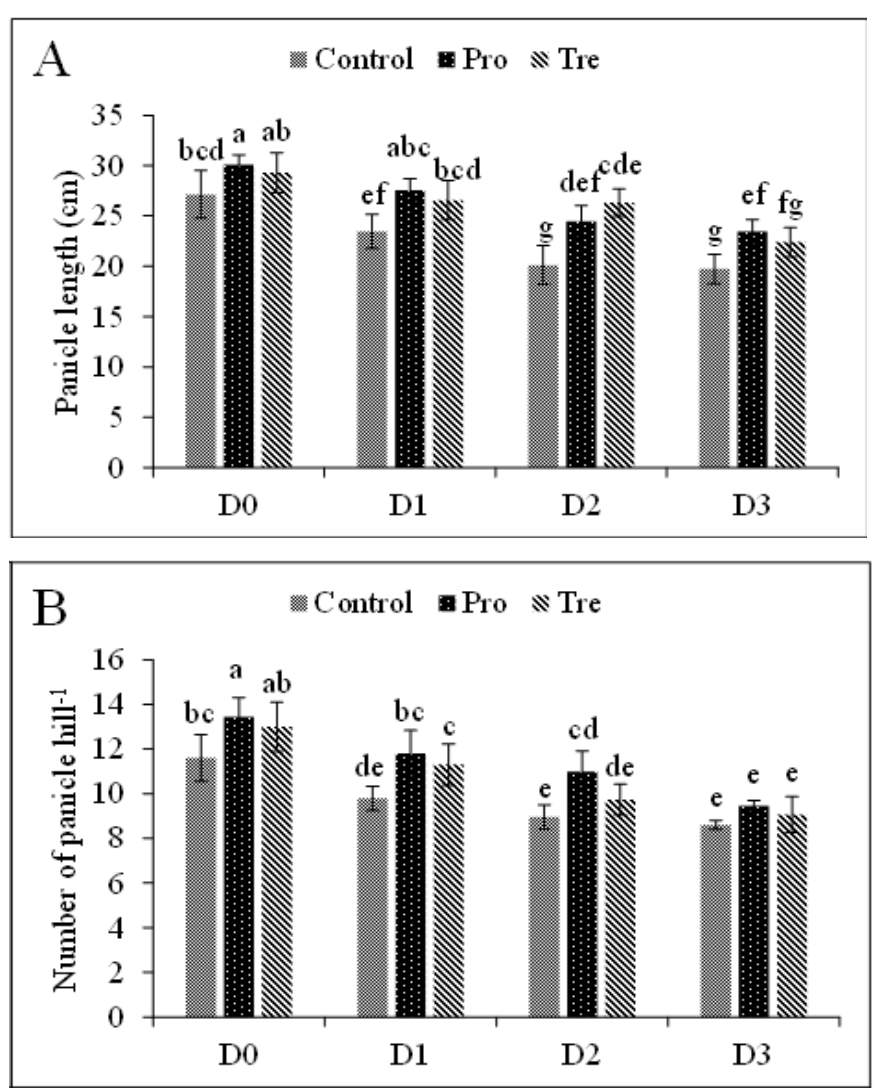

hough, application of protectants increased number of panicle hill ${ }^{-1}$ under stressed condition there were statistical-
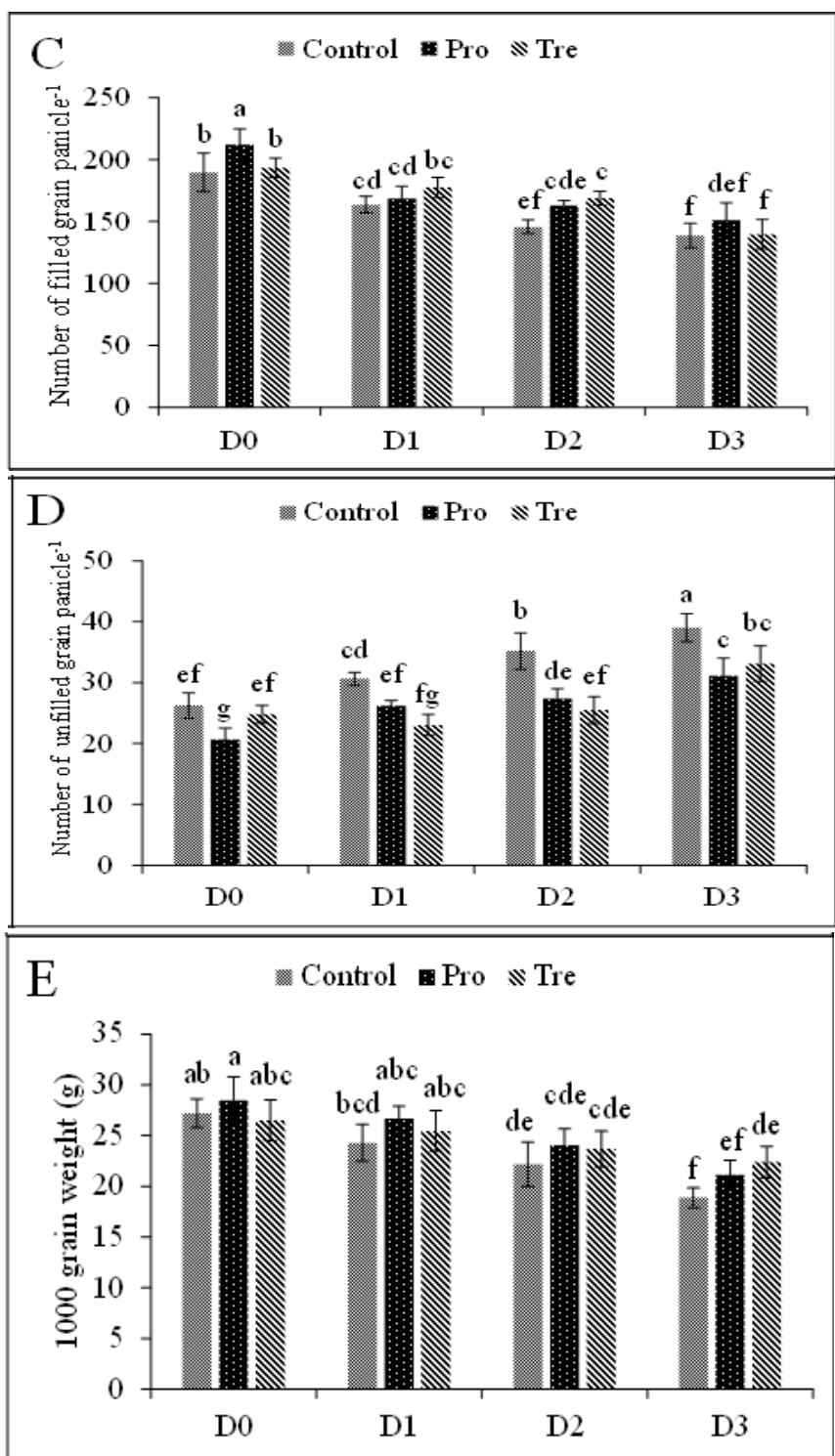

Fig. 5. Effect of different water deficit stress levels and foliar application of Pro and Tre on panicle length $(\mathbf{A})$, number of panicle hill ${ }^{-1}(\mathbf{B})$, number of filled grain panicle ${ }^{-1}(\mathbf{C})$, number of unfilled grain panicle ${ }^{-1}(\mathbf{D})$ and 1000 grain weight (E) of rice. Here, $D_{0}, D_{1}, D_{2}$ and $D_{3}$ denotes water deficit at panicle stage for $0,5,10$ and 15 days, respectively. Pro $=10 \mathrm{mM}$ proline, Tre $=10$ $\mathrm{mM}$ trehalose. Mean $( \pm \mathrm{SD})$ was calculated from three replicates for each treatment. Values with different letters are significantly different at $P \leq 0.05$ applying Fisher's LSD test 
ly same result observed under $D_{2}$ and $D_{3}$ condition with application of Pro and Tre. In unstressed condition, Pro increased $16 \%$ panicle number whereas $12 \%$ increase was resulted by Tre application.

\section{Number of grains panicle- ${ }^{1}$}

Both the numbers of filled and unfilled grain panicle ${ }^{-1}$ were impacted under prolonged water deficit stress condition. The highest filled grain was observed in well-irrigated condition where the lowest (27\%) filled grain was found under $\mathrm{D}_{3}$ water deficit stress condition (Fig. $5 \mathrm{C}$ ). Application of Pro and Tre further increased ( $12 \%$ and $2 \%)$ filled grain panicle ${ }^{-1}$ under unstressed condition, respectively. In $D_{1}$ and $D_{2}$ stressed condition Tre slightly increased number of panicle hill $^{-1}$ over the Pro compared to the respective control. At $D_{3}$ condition although Pro increased filled grain panicle ${ }^{-1}$ by $7 \%$, only $1 \%$ increase was incurred by Tre which was statistically similar to the respective control. Furthermore, unfilled grain panicle ${ }^{-1}$ increased with the increasing water deficit stress duration (Fig. 5 d). Application of Pro reduced unfilled grain panicle ${ }^{-1}$ by 17,30 and $30 \%$ under 5,10 and 15 days of water deficit stress condition, respectively.

\section{0-grain weight}

Decline in 1000 grain weight $(\mathrm{g})$ was recorded under water deficit stress (Fig. 5E). although drought stress reduced the 1000 grain weight, the lowest $(31 \%)$ was found at $D_{3}$ water deficit stress condition. However, osmolytes application resulted in increased grain weight under water deficit stress. Compared to control. the highest grain weight observed (13\%) after application of Tre at $D_{3}$ stress duration. On the contrary, though Pro and Tre increased grain weight but there was no statistical difference in $D_{1}$ and $D_{2}$ water deficit stress condition.

\section{Grain and straw yield}

Water deficit stress caused a considerable variation in terms of grain yield of rice (Fig. 6A). Drought for 15 days showed the highest reduction of grain yield $(29 \%)$ in rice. However, application of exogenous protectants significantly increased the grain yield. Proline increased grain yield by 8,8 and $6 \%$ while Tre increased 2,12 and $11 \%$ compared to respective control at $D_{1}, D_{2}$ and $D_{3}$ stress condition, respectively. Furthermore, in well-irrigated condition, application of Pro and Tre showed no significant difference. Rice plant exposed to water deficit stress resulted in the lowest straw yield $(23 \%)$ at $\mathrm{D}_{3}$ water deficit stress condition in contrast to control condition (Fig. 6B). Application of $10 \mathrm{mM}$ Pro at $\mathrm{D}_{1}$ stressed condition resulted with the highest (13\%) straw yield plant ${ }^{-1}$. On the contrary, Tre increased 5, 9 and $13 \%$ straw yield under $D_{1}, D_{2}$ and $D_{3}$ stress condition, respectively.

\section{Harvest index}

Harvest index was reduced due to the water deficit stress condition and osmolytes ameliorated the $\mathrm{HI}$ in rice plant (Fig. 6C). Compared to control condition, 12, 18 and 28\% HI was reduced under $D_{1}, D_{2}$ and $D_{3}$ water deficit condition, accordingly at the panicle stage. On the other hand, osmolytes such as Pro and Tre improved the $\mathrm{HI}$ in rice plant under different duration of water deficit stress. At $D_{3}$ stress condition, the highest (14\%) HI followed by $9 \%$ increase at $D_{2}$ was found while Pro was applied. In addition, Tre increased $\mathrm{HI}$ by 6,6 and $8 \%$ compared to respective water deficit stress condition.

\section{Discussion}

Water deficit stress is one of the crucial abiotic factors, which is responsible for the reduced growth and development of crop. Various biochemical and physiological functions like photosynthesis, respiration, translocation, ion uptake, nutrients and carbohydrate metabolism are significantly influenced by such condition (27). In addition, dehydration due to drought stress alters water relations, causes osmotic stress, inhibit cell expansion and division and the overall growth of plants (28). In this study, reduced plant
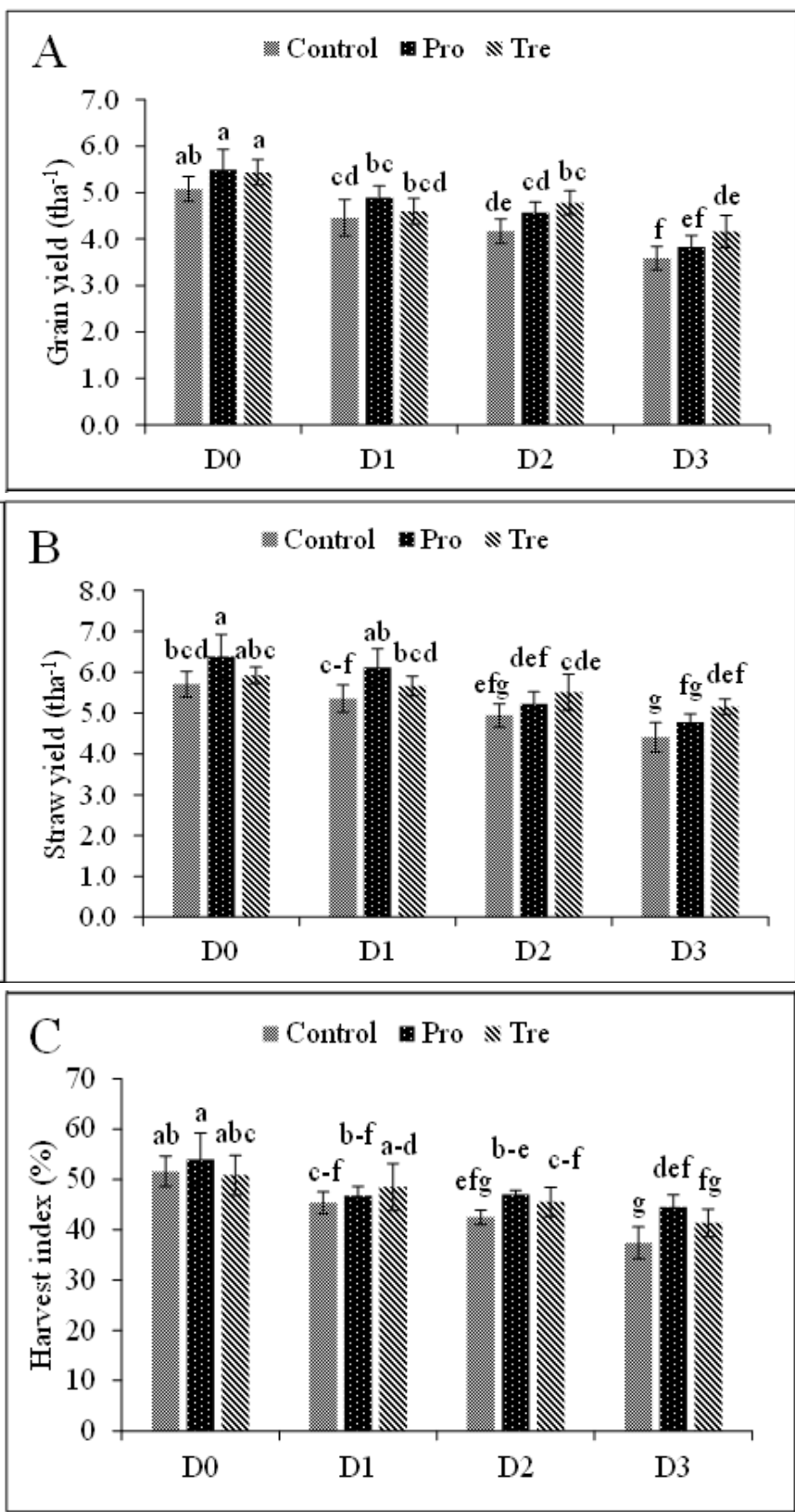

Fig. 6. Effect of different water deficit stress levels and foliar application of Pro and Tre on grain (A), straw yield (B) and harvest index (C) of rice. Here, $D_{0}, D_{1}, D_{2}$ and $D_{3}$ denotes water deficit at panicle stage for $0,5,10$ and 15 days, respectively. Pro $=10 \mathrm{mM}$ proline, Tre $=10 \mathrm{mM}$ trehalose. Mean $( \pm \mathrm{SD}$ ) was calculated from three replicates for each treatment. Values with different letters are significantly different at $P \leq 0.05$ applying Fisher's LSD test 
height was observed due to water deficit stress in a duration-dependent manner (Fig. 1) which be might due to dehydration of protoplasm including turgor loss and reduction of cell division and cell expansion (29). Under water deficit condition plant metabolic activity is greatly hampered due to lack of water. Hence, insufficient water supply reduced the turgor pressure, as a result cell division and cell elongation retarded and consequently plant height decreased (30). Similarly, reduced plant height along with decreased tillers plant $^{-1}$, biomass production and total grain yield was observed due to severe water deficit stress in rice plant (31). However, the current study showed that exogenous foliar application of Pro and Tre significantly enhanced the plant height which might be due to higher accumulation of osmolytes under water deficit stress condition which contribute to higher drought tolerance by adjusting the osmotic balance (32). A wide range of earlier reports corroborates our findings. Under drought condition, increased growth and biomass with exogenous Pro supplementation under drought condition were observed in Brassica species (33). Similarly, observations on increased growth, biomass and RWC of radish seedlings under drought condition treated with $25 \mathrm{mM}$ Tre was recorded (34). It was also observed that exogenous application of osmolytes modulates osmotic balance which helps to reduce water loss and thus increased plant height in Brassica rapa L. (35). Furthermore, increased plant height due to exogenous application of osmolytes under water deficit stress condition at vegetative and flowering stage was observed in Arachis hypogaea L. (36).

Water deficit stress also hampers the plant water relations; reduced leaf water content causes osmotic stress, which terminate the cell division and cell expansion as well as the total growth of the plant (37). Water deficit stressed rice plants have a lower RWC compared to control ones and decreased leaf water potential and transpiration rate, with a concomitant increase in leaf temperature (38). In this study, RWC of main leaf and flag leaf were reduced under different water deficit stress condition as shown in Fig. 2A, 2B. In a previous study, it was showed that the various effects of water deficit stress were recovered subsequently due to the accumulation of Pro and Tre at the growth stages of plant resulting the significant enhancement of RWC in main leaf (32). Relative water content of main leaf was decreased due to turgor loss under water deficit stress condition, which was recovered by the application of osmolytes (39). It was observed that among five varieties of rice, BRRI dhan 56 showed the least decrease of water content in both root and shoot due to highest accumulation of Pro in leaf under 10 days water deficit stress (40). Although water deficit stress drastically reduced RWC in this experiment, application of $10 \mathrm{mM}$ Pro and Tre notably re-established RWC. This finding clearly corroborates the earlier result observed (41) in rice cultivars where osmolytes under water deficit condition performed best in IR20 and PT1 variety. The water content and biomass production of plant was increased by the exogenous application of osmolytes such as Pro and Tre. Application of Pro and Tre significantly enhanced the water uptake under drought condition that might be due to the active role of these osmolytes in the osmotic adjustment of the plants (42).

Drought condition causes notable destruction in the photosynthetic ability of plants, which is principally due to dehydration that causes stomatal closure and limits $\mathrm{CO}_{2}$ diffusion. Moreover, inhibit the enzyme RuBisCo (Ribulose1,5-bisphosphate carboxylase/oxygenase), the nonstomatal factor (43). Drought-induced reduction of photosynthetic pigments might be due to the breakdown of pigments as well as their impaired biosynthesis. Photosynthesis has an important role in plant physiological process to regulate the growth and development of plants, and this process is very sensitive to water deficit stress in the higher plants. Chlorophyll content severely decreased under water deficit stress due to the destruction of chloroplast by active ROS (44). It was reported that the chl content of rice strongly decreased due to water deficit stress and salinity whereas the exogenous application of osmolytes such as Pro, Tre and GB retrieved better physiological condition under water deficit and salinity stress (45). For better crop, yield chl, plays a vital role in plant and thus has been considered as a vital element for photosynthesis process (46). Interaction of Tre and Pro under water deficit stress ameliorated the levels of photosynthetic pigments, which occurred due to significant biosynthesis of these pigments $(47,48)$. We observed the highest chl content in terms of SPAD value for Tre (19\%) at $D_{3}$ water deficit stress condition (Fig. 3A). Similarly, Timung and Bharali (49) concluded that the water deficit stress reduced the chl content significantly at the heading and maximum tillering stage. Flag leaf sheath, culm and internodes play significant role by transporting carbohydrate and increasing photo assimilates production rate during grain filling stage (50). The chl content of flag leaf was declined under prolonged water deficit stress for several days and protectants ameliorated this condition is shown in Fig. 3A, 3B. Similarly, it was observed that chl content of flag leaf was decreased due to water deficit stress which might be associated with amino acid and soluble protein levels likely to be decreased (51). It was also found that the foliar application of Tre significantly enhanced the photosynthetic activity and improved the plant biomass production between plant-water relationship including solute potential, water potential and turgor potential (52).

The tillering capacity is the major characteristics of the plant and it plays a significant contribution to the evaluation of grain yield. Number of effective tillers hill-1 is an important parameter that reveals the total plant area and crop leaf area index which greatly reduced under water deficit stress condition (53). The plant survival and tillering ability partially rely on the various environmental factors like soil water relations, nutritional status, temperature, radiation and varietal traits. Number of effective tillers hill ${ }^{-}$ 1also increased with the application of osmolytes than the well-irrigated condition shown in Fig. 4A. Likewise, it was stated that exogenous application of osmoprotectants increased tillers hill ${ }^{-1}$ with increasing the level of water deficit stress resulting the decreased non-effective tillers hill ${ }^{-1}(54)$.

Highest number of non-effective tillers hill-1 was observed at $D_{3}$ stress conditions shown in Fig. 4B. Similarly, It 
was showed that among six rice varieties, the highest number of non-effective tillers hill-1 was observed in Binadhan13 and NERICA mutant under drought stress at $40 \%$ field capacity (41). The exogenous application of osmolytes reduced the non-effective tillers in rice. If the unproductive tillers are diminished or eliminated, it is not clear that the yield potential of rice could be more increased where tillering capacity of rice is one of the most important characters (55). The rate of grain yield production of rice plants also influenced by the panicle bearing tillers where the over tillering leads the abortion of tillers, poor grain yield and reduced panicle size (56). It was stated that the water deficit stress causes delayed flowering, diminished the number of effective tillers hill $^{-1}$ responsible for increased the unproductive tillers panicle ${ }^{-1}(57)$. Generally, more than $40 \%$ unproductive tillers have been produced where these kinds of tiller don't show any performance to the ultimate grain yield of the crops. The mineral nutrients also consumed, assimilates and generated by the crop plants in the middle growth stage, thereby the availability of grain filling resources was drastically reduced under stressed condition.

Water deficit stress hamper the panicle development specially affects at the reproductive stage of the plant. Water deficit stress was more deleterious at anthesis to maturity (grain filling) stage followed by the panicle initiation. Due to diminished photosynthetic activity, the assimilates generation greatly minimized thus the panicles growth and ultimately total rice production was greatly reduced (58). Effect of osmolytes causes the panicle length gradually enhanced than the respective control condition of the plant shown in Fig. 5A. Similarly, both Tre and Pro under water deficit stress condition maintain the tolerance mechanism of plants when the osmolytes also accumulated at more amounts (59). Due to the effect of water, deficit stress the number of panicle hill ${ }^{-1}$ was significantly reduced shown in Fig. 5B. Similarly, it was concluded that the crop yield could be decreased up to $30 \%$ owing to diminished number of panicle hill ${ }^{-1}(60)$. It was stated that the number of panicles hill $^{-1}$ was closely interlinked with grain production (61).

Filled grain panicle ${ }^{-1}$ was decreased when less amount of assimilates transferred to the grains of the plants. Total grain yield was gradually reduced by the effect of water deficit stress on flowering stage where the total filled grain panicle ${ }^{-1}$ was reduced without the substantial mitigation of filled grain panicle ${ }^{-1}$ (62). Total number of filled grain was enhanced due to the performance of carbohydrate from photosynthesis, which was transferred to the grain and contribution to the grain yield. It was reported that there are two water deficit stress tolerant rice varieties like N22 and Dular did not give any momentous reduction for filled grain and grain yield contrast to control plants whereas the water deficit stress intolerant varieties give serious reduction but minimize these problems by the exogenous application of osmolytes (63). Likewise, the filled grain panicle ${ }^{-1}$ was remarkably reduced under water deficit stress condition shown in Fig. $5 \mathrm{C}$ and the foliar application of osmolytes causes for the grain panicle ${ }^{-1}$ was enhanced compared to their respective control. The period of panicle initiation was delayed due to water deficit stress and re- tarded the development of panicle at any stage up to flowering, which ultimately affected the grain panicle ${ }^{-1}$ causes for reduction of total yield of the crop (64). Studies exposed that various yield parameters like length of panicle, grain weight panicle ${ }^{-1}$, grains panicle ${ }^{-1}$ are significantly diminished by the effect of water deficit stress in rice (65).

It was stated that the water deficit stress diminished the grain production, 1000 grain weight, $\mathrm{HI}$ but also increased the unfilled grain panicle ${ }^{-1}(66)$. Water deficit stress before panicle starting decreased the number of grain potentiality and assimilates translocation to the grains resulting lower the grain weight and enhance the number of empty grain or unfilled grain (67). Exogenous application of osmolytes reduced the unfilled grain panicle ${ }^{-1}$ shown in Fig. $5 \mathrm{~d}$. The period of grain filling presumably decreased due to decreased photosynthesis under water drought condition in the plants resulting the enhanced the amount of empty grain panicle ${ }^{-1}$. The highest amount of unfilled grain panicle ${ }^{-1}$ was observed at $\mathrm{D}_{3}$ water deficit stress. Unfilled grain pan$i \mathrm{icl}^{-1}$ was increased under water deficit stress owing to dryness of inactive pollen grain, partial pollen tube advancement; incomplete assimilates generation and its allocation to grains. The similar result also revealed that diversified chemical nature of osmolytes differ from each other while regulating the osmotic balance and also act in opposition to oxidative stress (68). Thus, the unfilled grain was decreased by the exogenous application of osmolytes.

The water deficit stress significantly affected the yield components resulting in the reduction of different yield promoting characters such as tillers hill-1 ${ }^{-1}$, panicle development, spikelet panicle ${ }^{-1}$, grain weight, total grain yield and biological yield. Water deficit stress primarily hampers the kernel development of grain. It decreased notably during the linear fill period which directly impedes the enzymatic activity or during the development of other stage resulting premature desiccation of panicle (69). Due to water deficit stress 1000 -grain weight was significantly reduced which eventually enhanced by the application of osmolytes (Fig. 5E). Likewise, it was reported that water deficit condition greatly diminished the 1000grain weight, straw yield and $\mathrm{HI}$ in canola (70). Reduction of photosynthesis production and their transfers to the reproductive organ like grains owing to water deficit stress ultimately reduce 1000-grain weight (71). Foliar application of Pro and Tre has been demonstrated to enhance the number of effective tillers, fertile grain, total biomass production, grain panicle ${ }^{-1}$, 1000 -grain weight and total grain yield of the crops (72). Exogenous application of Pro, GB and Tre further reported that germination, seedling growth, chl content, 1000-grain weight, total number of grains panicle ${ }^{-1}$ and ultimately the total grain yield were increased under water deficit stress (73).

The straw yield was greatly interlinked to grain production these the two traits were positively connected to plant height before crop harvesting. It was concluded that water deficit stress has a detrimental effect on plant water relations during flowering period and ear formation and it diminished the grain yield by $37 \%$ and straw yield by $18 \%$ (39). Due to the effect of water deficit stress the straw yield 
was decreased shown in Fig. 6B. Similarly, it was found that under water deficit condition straw yield significantly reduced and also accompanied by lignin, pectin and cellulose percentage which was concurrent with sharply declined of soluble sugar content in the straw yield (74). Reports are on straw production and $\mathrm{HI}$ are sensitive to water deficit stress for different cultivars of rice (75). Generally, different kinds of inorganic and organic solutes were accumulated in the cytosol of plants like Pro, which provided tolerance mechanism in opposition to oxidative stress and it was also considered as a major strategy to cope with the pernicious effect of water deficit stress to regulated the driving gradients and turgor pressure for sufficient amount of water uptake (76).

Harvest index indicates that it's a ratio between two parameters such as grain yield and biological yield. Harvest index determined from the dry matter partitioning between the cereal grains and other parts of the plant. As the severity of water deficit stress enhanced, the photosynthetic activity, plant height, grain filling, water potential, 1000-grain weight and $\mathrm{HI}$ significantly decreased (77). Total grain production was positively linked with straw yield, $\mathrm{HI}$ under water deficit stress condition during the grain filling stage. The grain yield was reduced from 14 to $57 \%$ by the effect of water deficit stress, while $\mathrm{HI}$ and straw yield were not significantly invaded by water deficit stress than total grain yield (78).
Plant height and SPAD value were increased in our experiment with the application of osmolytes. Foliar application of osmolytes may have been triggered the biosynthesis and increased the internal supply of Pro and Tre under drought stress that in turn highly accumulated chl and reduced the membrane damage in the cell (79). Increased RWC was also observed in our study which might be due to higher accumulation of soluble sugars work as an osmoprotectant to prevent water loss from plant cells under osmotic stresses (80). Earlier findings support that Tre in saline medium protects Catharanthus roseus from the inhibitory effects of salt on growth, RWC and photosynthesis (81, 82). Increased osmolytes levels under stress condition significantly affect the regulation of carbon allocation and utilization in plants resulting in yield improvements (83). Moreover, increased soluble sugar production may also accelerate starch accumulation in leaves as a temporary carbon reserve and as a primary component of dry matter accumulation. This higher starch and glucose assimilation under water deficit stress by osmolytes may have resulted in positive correlations between various yield parameters, and hence improved total grain yield in our experiment. In plants naturally produced osmolytes play the vital role in osmotic adjustment by stabilizing sub-cellular structures such as, membranes, proteins, macromolecules, photosynthetic pigments. Furthermore, osmolytes stabilize the cellular redox potential by scavenging the toxic ROS free radicals from cell (84). Osmolytes raise cellular osmotic pres-

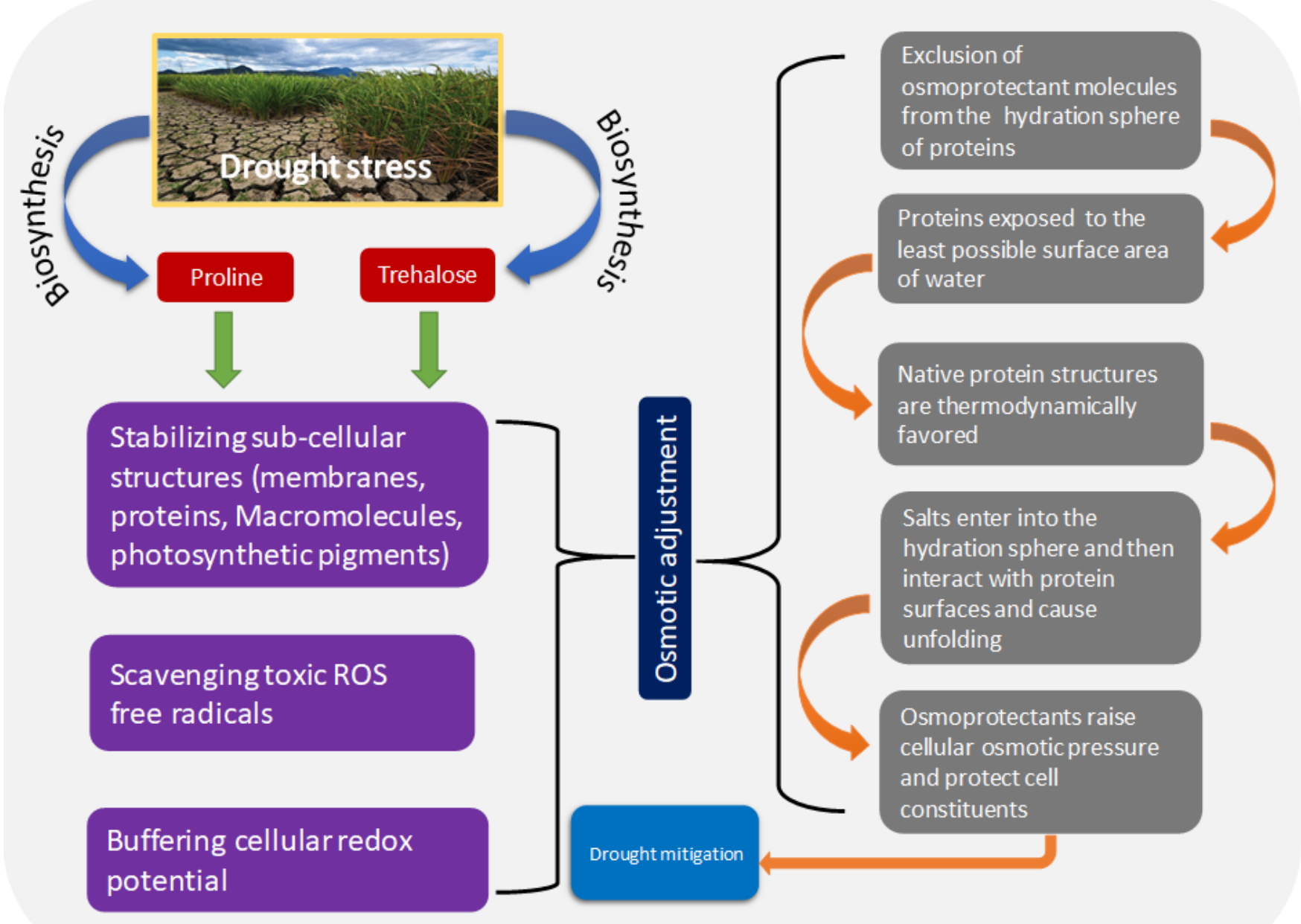

Fig. 7. Mechanism responsible for water-deficit stress mitigation by poline and trehalose 
sure and protect cell constituents under both drought and salinity (Fig. 7). The fundamental basis of protective effect by osmolytes involves the exclusion of osmoprotectant molecules from the hydration sphere of proteins. As a result, proteins are exposed to the least possible surface area of water. Thus, inherent protein structures are thermodynamically favoured. Salts enter into the hydration sphere and then interact with protein surfaces and cause unfolding (85).

\section{Conclusion}

Water deficit stress is the most pernicious type of abiotic stress that considerably reduces plant morphological, physiological and yield parameters in rice plant. In our study, it was observed that prolonged water deficit condition causes notable reduction in plant height, RWC and SPAD value in rice plant whereas non-effective tillers hill ${ }^{-1}$, unfilled grain panicle ${ }^{-1}$ was evidently increased with increasing water deficit stress duration. However, the application of osmolytes such as Pro and Tre considerably improved the yield parameters such as number of panicle hill-1, panicle length and number and filled grain panicle ${ }^{-1}$. It was also observed that $10 \mathrm{mM}$ Pro foliar spray performed better under water deficit condition at panicle stage for 5 days while $10 \mathrm{mM}$ Tre was effective in elevating water deficit stress effect on yield contributing characters under water deficit condition for 10 days. Therefore, future research should be done using with different other osmolytes with different application doses and methods concentrations to realize either plant can effectively minimize water deficit stress effect in rice plants at different growth stages.

\section{Acknowledgements}

We are grateful to the Farm Management Wing of Sher -e-Bangla Agricultural University (SAU) for experimental supports. The authors also express their gratitude and thanks to Mira Rahman and Khadeja Sultana Sathi, Department of Agronomy, SAU for their assistant during data collection.

\section{Authors contributions}

MNI performed the experiment; AACM performed the experiment and prepared the manuscript draft; MMA performed and coordinated the experiment; MNI conducted the experiment; MLR provided the research materials and conducted the experiment; $\mathrm{MH}$ designed the experiment, analyzed the data, edited the manuscript and supervised the entire experiment. All authors read and approved the final manuscript.

\section{Compliance with ethical standards}

Conflict of interest: The author(s) declare that they have no competing interests.

Ethical issues: None.

\section{References}

1. Devireddy AR, Zandalinas SI, Fichman Y, Mittler R. Integration of reactive oxygen species and hormone signaling during abiotic stress. Plant J. 2021;105:459-76.

2. Rabiei Z, Roshan NM, Sadeghi SM, Amiri E, Doroudian HR. Effect of drought stress and different levels of nitrogen and potassium fertilizers on the accumulation of osmolytes and chlorophyll in rice (Oryza sativa L.). Gesunde Pflanzen. 2021; https:// doi.org/10.1007/s10343-021-00550-w

3. Per TS, Khan NA, Reddy PS, Masood A, Hasanuzzaman M, Khan MI, Anjum NA. Approaches in modulating proline metabolism in plants for salt and drought stress tolerance: Phytohormones, mineral nutrients and transgenics. Plant Physiol Biochem. 2017;115:126-40.

4. Rahdari P, Hoseini SM. Drought stress, a review. Int J Agron Plant Prod. 2012;3:443-46.

5. Wang X, Mao Z, Zhang J, Hemat M, Huang M, Cai J, Zhou Q, Dai T, Jiang D. Osmolyte accumulation plays important roles in the drought priming induced tolerance to post-anthesis drought stress in winter wheat (Triticum aestivum L.). Environ Exp Bot. 2019;166:103804. https://doi.org/10.1016/ j.envexpbot.2019.103804

6. Demirevska K, Simova-Stoilova L, Fedina I, Georgieva K, Kunert K. Response of oryzacystatin I transformed tobacco plants to drought, heat and light stress. J Agron Crop Sci. 2010;196:90-99.

7. Hasanuzzaman M, Anee TI, Bhuiyan TF, Nahar K, Fujita M. Emerging role of osmolytes in enhancing abiotic stress tolerance in rice. In: Hasanuzzaman M, Fujita M, Nahar K, Biswas JK, editors. Advances in Rice Research for Abiotic Stress Tolerance. Elsevier, Amsterdam; 2019. p. 677-708.

8. Rawat N, Singla-Pareek SL, Pareek A. Membrane dynamics during individual and combined abiotic stresses in plants and tools to study the same. Physiol Plant. 2021;71:653-76.

9. Khan MN, Zhang J, Luo T, Liu J, Ni F, Rizwan M, Fahad S, Hu L. Morpho-physiological and biochemical responses of tolerant and sensitive rapeseed cultivars to drought stress during early seedling growth stage. Acta Physiol Plant. 2019;41:25. https:// doi.org/10.1007/s11738-019-2812-2

10. El Sabagh A, Hossain A, Barutcular C, Gormus O, Ahmad Z, Hussain S, Islam MS, Alharby H, Bamagoos A, Kumar N, Akdeniz $\mathrm{H}$. Effects of drought stress on the quality of major oilseed crops: implications and possible mitigation strategies-a review. Appl Ecol Environ Res. 2019;17:4019-43.

11. Rady MM, Boriek SH, El-Mageed A, Taia A, Seif El-Yazal MA, Ali EF, Hassan FA, Abdelkhalik A. Exogenous gibberellic acid or dilute bee honey boosts drought stress tolerance in Vicia faba by rebalancing osmoprotectants, antioxidants, nutrients and phytohormones. Plants. 2021;10:748. https://doi.org/10.3390/ plants 10040748

12. Hadiarto T, Tran LS. Progress studies of drought-responsive genes in rice. Plant Cell Rep. 2011;30:297-310.

13. Khater MA, Dawood MG, Sadak MS, Shalaby MA, El-Awadi ME, ElDin KG. Enhancement the performance of cowpea plants grown under drought conditions via trehalose application. Middle East J. 2018;7:782-800.

14. AlKahtani MD, Hafez YM, Attia K, Rashwan E, Husnain LA, AlGwaiz $\mathrm{HI}$, Abdelaal KA. Evaluation of silicon and proline application on the oxidative machinery in drought-stressed sugar beet. Antioxidants. 2021;10:398. https://doi.org/10.3390/antiox10030398

15. Gupta P, Rai R, Sujata V, Yadava DK, Dash PK. Ex-foliar application of glycine betaine and its impact on protein, carbohydrates and induction of ROS scavenging system during drought stress in flax (Linum usitatissimum). J Biotechnol. 2021;337:80-89.

16. Signorelli S, Coitiño EL, Borsani O, Monza J. Molecular mecha- 
nisms for the reaction between $\mathrm{OH}$ radicals and proline: insights on the role as reactive oxygen species scavenger in plant stress. J Phys Chem B. 2013;118:37-47.

17. Farooq M, Wahid A, Lee DJ, Cheema SA, Aziz T. Comparative time course action of the foliar applied glycinebetaine, salicylic acid, nitrous oxide, brassinosteroids and spermine in improving drought resistance of rice. J Agron Crop Sci. 2010;196:336-45.

18. Kosar F, Akram NA, Ashraf M, Ahmad A, Alyemeni MN, Ahmad P. Impact of exogenously applied trehalose on leaf biochemistry, achene yield and oil composition of sunflower under drought stress. Physiol Plant. 2021;172:317-33.

19. Szabados L, Savoure A. Proline: a multifunctional amino acid. Trends Plant Sci. 2010;15:89-97.

20. Hayat S, Hayat Q, Alyemeni MN, Wani AS, Pichtel J, Ahmad A. Role of proline under changing environments: a review. Plant Signal Behav. 2012;7:1456-66.

21. Kamran M, Shahbaz M, Ashraf M, Akram NA. Alleviation of drought induced adverse effects in spring wheat (Triticum aestivum). Using proline as a pre-sowing seed treatment. Pak J Bot. 2009;41:621-32.

22. Farooq M, Basra SM, Wahid A, Cheema ZA, Cheema MA, Khaliq A. Physiological role of exogenously applied glycinebetaine to improve drought tolerance in fine grain aromatic rice (Oryza sativa L.). J Agron Crop Sci. 2008;194:325-33.

23. BARC. Fertilizer Recommendation Guide, Bangladesh Agricultural Research Council, Farmgate, Dhaka, Bangladesh, 2018.

24. Barrs HD, Weatherley PE. A re-examination of the relative turgidity technique for estimating water deficits in leaves. Aust $\mathrm{J}$ Biol Sci. 1962;15:413-28.

25. Yuan Z, Cao Q, Zhang K, Ata-Ul-Karim ST, Tian Y, Zhu Y, Cao W, Liu X. Optimal leaf positions for SPAD meter measurement in rice. Front Plant Sci. 2016;7:719. https://doi.org/10.3389/ fpls.2016.00719

26. CoStat. CoStat-Statistics Software version 6.400. CoHort Software. 798 Lighthouse Ave, PMB 320, Monterey, CA, 93940, USA, 2008.

27. Hussain HA, Hussain S, Khaliq A, Ashraf U, Anjum SA, Men S, Wang L. Chilling and drought stresses in crop plants: implications, cross talk and potential management opportunities. Front Plant Sci. 2018;9:393. https://doi.org/10.3389/fpls.2018.00393

28. Hasanuzzaman M, Nahar K, Anee TI, Khan MI, Fujita M. Siliconmediated regulation of antioxidant defense and glyoxalase systems confers drought stress tolerance in Brassica napus L. S Afr J Bot. 2018;115:50-57.

29. Ahmad A, Aslam Z, Iqbal N, Idrees M, Bellitürk K, Rehman SU, Ameer H, Ibrahim MU, Samiullah, Rehan M. Effect of exogenous application of osmolytes on growth and yield of wheat under drought conditions. J Environ Agric Sci. 2019;21:6-13.

30. Singh S, Prasad S, Yadav V, Kumar A, Jaiswal B, Kumar A, Khan NA, Dwivedi DK. 2018; Effect of drought stress on yield and yield components of rice (Oryza sativa L.) genotypes. Int J Curr Microbiol Appl Sci. 7:2752-59.

31. Tuteja N, Sahoo RK, Garg B, Tuteja R. OsSUV3 dual helicase functions in salinity stress tolerance by maintaining photosynthesis and antioxidant machinery in rice (Oryza sativa L. cv. IR64). Plant J. 2013;76:115-27.

32. Dien DC, Mochizuki T, Yamakawa T. Effect of various drought stresses and subsequent recovery on proline, total soluble sugar and starch metabolisms in rice (Oryza sativa L.) varieties. Plant Prod Sci. 2019;22:530-45.

33. Alam MM, Nahar K, Hasanuzzaman M, Fujita M. Trehaloseinduced drought stress tolerance: A comparative study among different Brassica species. Plant Omics. 2014;7:271-83.

34. Akram NA, Waseem M, Ameen R, Ashraf M. Trehalose pretreat- ment induces drought tolerance in radish (Raphanus sativus L.) plants: some key physio-biochemical traits. Acta Physiol Plant. 2016;38:3. https://doi.org/10.1007/s11738-015-2018-

35. Bhuiyan TF, Ahamed KU, Nahar K, Al Mahmud J, Bhuyan MB, Anee TI, Fujita M, Hasanuzzaman M. Mitigation of PEG-induced drought stress in rapeseed (Brassica rapa L.) by exogenous application of osmolytes. Biocatal Agric Biotechnol. 2019;20:101197. https://doi.org/10.1016/j.bcab.2019.101197

36. Zhang M, Wang LF, Zhang K, Liu FZ, Wan YS. drought-induced responses of organic osmolytes and proline metabolism during pre-flowering stage in leaves of peanut (Arachis hypogaea L.). J Integr Agric. 2017;16:2197-2205.

37. Alam MM, Hasanuzzaman M, Nahar K, Fujita M. Exogenous salicylic acid ameliorates short-term drought stress in mustard (Brassica juncea L.) seedlings by upregulating the antioxidant defense and glyoxalase system. Aust J Crop Sci. 2013;7:1053-63.

38. Fahad S, Bajwa AA, Nazir U, Anjum SA, Farooq A, Zohaib A, Sadia S, Nasim W, Adkins S, Saud S, Ihsan MZ. Crop production under drought and heat stress: plant responses and management options. Front Plant Sci. 2017;8:1147. https://doi.org/10.3389/ fpls.2017.01147

39. Katerji N, Mastrorilli M, Van Hoorn JW, Lahmer FZ, Hamdy A, Oweis T. Durum wheat and barley productivity in saline drought environments. Euro J Agron. 2009;31:1-9.

40. Saha S, Begum HH, Nasrin S. Effects of drought stress on gowth and accumulation of proline in five rice varieties (Oryza sativa L.). J Asiatic Soc Bangladesh Sci. 2019;45:241-47.

41. Moonmoon S, Fakir M, Islam M. Effect of drought stress on grain dry weight, photosynthesis and chlorophyll in six rice genotypes. Sch J Agric Vet Sci. 2017;4:13-17.

42. Hanif S, Saleem MF, Sarwar M, Irshad M, Shakoor A, Wahid MA, Khan $\mathrm{HZ}$. Biochemically triggered heat and drought stress tolerance in rice by proline application. J Plant Growth Regul. 2021;40:305-12.

43. Perdomo JA, Capó-Bauçà S, Carmo-Silva E, Galmés J. Rubisco and rubisco activase play an important role in the biochemical limitations of photosynthesis in rice, wheat and maize under high temperature and water deficit. Front Plant Sci. 2017;8:490. https://doi.org/10.3389/fpls.2017.00490

44. Anjum SA, Xie XY, Wang LC, Saleem MF, Man C, Lei W. Morphological, physiological and biochemical responses of plants to drought stress. Afr J Agric Res. 2011;6:2026-32.

45. Kadhimi AA, Zain CR, Alhasnawi AN, Isahak A, Ashraf MF, Mohamad A, Doni F, Yusoff WM. Effect of irradiation and polyethylene glycol on drought tolerance of MR269 genotype rice (Oryza sativa L.). Asian J Crop Sci. 2016;8:52-59.

46. Nahar K, Hasanuzzaman M, Alam MM, Fujita M. Exogenous glutathione induced drought stress tolerance in mungbean (Vigna radiata L.) seedlings: coordinated roles of the antioxidant defence and methylglyoxal detoxification system. AoB plants. 2015; plv069. https://doi.org/10.1093/aobpla/plv069

47. Hoque MA, Banu MN, Nakamura Y, Shimoishi Y, Murata Y. Proline and glycinebetaine enhance antioxidant defense and methylglyoxal detoxification systems and reduce $\mathrm{NaCl}$-induced damage in cultured tobacco cells. J Plant Physiol. 2007;165:813-24.

48. Kosar F, Akram NA, Ashraf MU, Sadiq MU, Al-Qurainy F. Trehalose -induced improvement in growth, photosynthetic characteristics and levels of some key osmoprotectants in sunflower (Helianthus annuus L.) under drought stress. Pak J Bot. 2018;50:955-61.

49. Timung B, Bharali B. Biochemical indicators in upland rice (Oryza sativa L.) under physiological drought condition. J Pharmacog Phytochem. 2020;9:1825-33.

50. Biswal AK, Kohli A. Cereal flag leaf adaptations for grain yield under drought: Knowledge status and gaps. Mol Breed. 
2013;31:749-66.

51. Saha K, Gupta K. Effect of LAB 150974 a plant growth retardant two rice seedlings under drought. Indian J Plant Physiol.1993;36:151-54.

52. Ali Q, Ashraf M. Induction of drought tolerance in maize (Zea mays L.) due to exogenous application of trehalose: growth, photosynthesis, water relations and oxidative defence mechanism. J Agron Crop Sci. 2011;197:258-71.

53. Ibrahim HA, Samiullah MR. Effect of exogenous application of osmolytes on growth and yield of wheat under drought conditions. J Environ Agric Sci. 2010;21:06-13.

54. Herath HM, Bandara DC, Weerasinghe PA, Iqbal MC, Wijayawardhana HCD. Effect of osmolytes on growth parameters and plant accumulation in different rice (Oryza sativa L.) varieties in Sri Lanka. Trop Agric Res. 2014;25:532-42.

55. Ao H, Peng S, Zou Y, Tang Q, Visperas RM. Reduction of unproductive tillers did not increase the grain yield of irrigated rice. Field Crops Res. 2010;116:108-15.

56. Badshah MA, Naimei T, Zou Y, Ibrahim M, Wang K. Yield and tillering response of super hybrid rice Liangyoupeijiu to tillage and establishment methods. Crop J. 2014;2:79-86.

57. Abd El-Mageed TA, El-Sherif AM, Ali MM, Abd El-Wahed MH. Combined effect of deficit irrigation and potassium fertilizer on physiological response, plant water status and yield of soybean in calcareous soil. Arch Agron Soil Sci. 2017;63:827-40.

58. Sharifunnessa M, Islam MT. Effect of drought stress at different growth stages on yield and yield components of six rice (Oryza sativa L.) genotypes. Fund Appl Agric. 2017;2:285-89.

59. Paul S, Roychoudhury A. Comparative analysis of the expression of candidate genes governing salt tolerance and yield attributes in two contrasting rice genotypes, encountering salt stress during grain development. J Plant Growth Regul. 2019;38:539-56.

60. Boonjung $\mathrm{H}$, Fukai S. Effects of soil water deficit at different growth stages on rice growth and yield under upland conditions. 1. Growth during drought. Field Crops Res. 1996;48:47-55.

61. Krishnan P, Ramakrishnan B, Reddy KR, Reddy VR. Hightemperature effects on rice growth, yield and grain quality. Advan Agron. 2011;111:87-206.

62. Nahar S, Vemireddy LR, Sahoo L, Tanti B. Antioxidant protection mechanisms reveal significant response in drought-induced oxidative stress in some traditional rice of Assam, India. Rice Sci. 2018;25:185-96.

63. Casartelli A, Riewe D, Hubberten HM, Altmann T, Hoefgen R, Heuer S. Exploring traditional aus-type rice for metabolites conferring drought tolerance. Rice. 2018;11:1-6.

64. Prasad PV, Staggenborg SA, Ristic Z. Impacts of drought and heat stress on physiological, developmental, growth and yield processes of crop plants. In:Ahuja LR, Reddy VR, Saseendran SA, Yu $\mathrm{Q}$, editors. Response of crops to limited water: Understanding and modeling water stress effects on plant growth processes, Volume 1, John Wiley \& Sons, Inc, Madison, USA, 2008. p. 301-55.

65. Upadhyaya $\mathrm{H}$, Panda SK. Drought stress responses and its management in rice. In:Hasanuzzaman M, Fujita M, Biswas JK, editors. Advances in rice research for abiotic stress tolerance. Elsevier, Netherlands, 2019. p. 177-200.

66. Hemmati MH, Soleymani A. A study about drought stress effects on grain yield components of three sunflower cultivars. Int J Adv Biol Biomed Res. 2014;2:564-72.

67. Zubaer MA, Chowdhury AK, Islam MZ, Ahmed T, Hasan MA. 2007; Effects of water stress on growth and yield attributes of aman rice genotypes. Int J Sustain Crop Prod. 2:25-30.

68. Nawaz M, Wang Z. Abscisic acid and glycine betaine mediated tolerance mechanisms under drought stress and recovery in Axonopus compressus: A new insight. Sci Rep. 2020; 10:6942. https://doi.org/10.1038/s41598-020-63447-0

69. Nayyar H, Walia DP. Genotypic variation in wheat in response to water stress and abscisic acid-induced accumulation of osmolytes in developing grains. J Agron Crop Sci. 2004; 190:39-45.

70. Masoud SMJ. The effect of water deficit during growth stages of canola. Am Eur J Agric Environ Sci.2007;2:417-22.

71. Asch F, Dingkuhn M, Sow A, Audebert A. Drought induced changes in rooting patterns and assimilate partitioning between root and shoot in upland rice. Field Crops Res.2005;93:223-36.

72. Raza MA, Saleem MF, Shah GM, Khan IH, Raza A. Exogenous application of glycinebetaine, proline and trehalose for improving water relations and grain yield of wheat under drought. J Soil Sci Plant Nutr. 2014;14:348-64.

73. Rehman MT, Islam MT, Islam MO. Effect of water stress at different growth stages on yield and yield contributing characters of transplanted aman rice. J Agron Crop Sci. 2002; 199:12-22.

74. Emam MM, Khattab HE, Helal NM, Deraz AE. Effect of selenium and silicon on yield quality of rice plant grown under drought stress. Aust J Crop Sci. 2014;8:596-605.

75. Akram M. Growth and yield components of wheat under water stress of different growth stages. Bangladesh J Agric Res. 2011;36:455-68.

76. Johari-Pireivatlou M. Effect of soil water stress on yield and proline content of four wheat lines. Afr J Biotechnol. 2010;9:417-511.

77. Samarah NH, Alqudah AM, Amayreh JA, McAndrews GM. The effect of late-terminal drought stress on yield components of four barley cultivars. J Agron Crop Sci. 2009;195:427-41.

78. Kottmann L, Wilde P, Schittenhelm S. How do timing, duration and intensity of drought stress affect the agronomic performance of winter rye. Euro J Agron. 2016;75:25-32.

79. Joshi R, Sahoo KK, Singh AK, Anwar K, Pundir P, Gautam RK, Krishnamurthy SL, Sopory SK, Pareek A, Singla-Pareek SL. Enhancing trehalose biosynthesis improves yield potential in marker-free transgenic rice under drought, saline and sodic conditions. J Exp Bot. 2020;71:653-68.

80. Delorge I, Janiak M, Carpentier S, Van Dijck P. Fine tuning of trehalose biosynthesis and hydrolysis as novel tools for the generation of abiotic stress tolerant plants. Front Plant Sci. 2014;5:147. https://doi.org/10.3389/fpls.2014.00147

81. Chang B, Yang L, Cong W, Zu Y, Tang Z. The improved resistance to high salinity induced by trehalose is associated with ionic regulation and osmotic adjustment in Catharanthus roseus. Plant Physiol Biochem. 2014;77:140-48.

82. Oszvald M, Primavesi LF, Griffiths CA, Cohn J, Basu SS, Nuccio ML, Paul MJ. Trehalose 6-phosphate regulates photosynthesis and assimilate partitioning in reproductive tissue. Plant Physiol. 2018;176:2623-38.

83. Paul MJ, Oszvald M, Jesus C, Rajulu C, Griffiths CA. Increasing crop yield and resilience with trehalose 6-phosphate: targeting a feast-famine mechanism in cereals for better source-sink optimization. J Exp Bot. 2017;68:4455-62.

84. Abdallah MM, El Sebai TN, Ramadan AA, El-Bassiouny HM. Physiological and biochemical role of proline, trehalose and compost on enhancing salinity tolerance of quinoa plant. Bull Natl Res Cent. 2020;44:1-13.

85. Nahar K, Hasanuzzaman M, Fujita M. Roles of osmolytes in plant adaptation to drought and salinity. In: Iqbal N, Nafees RN, Khan $A$, editors. Osmolytes and plants acclimation to changing environment: Emerging omics technologies. Springer, New Delhi; 2016. p. 37-68 